\title{
Assessing ridden horse behavior: Professional judgment and physiological measures
}

Carol Hall*, Rachel Kay ${ }^{1}$, Kelly Yarnell ${ }^{1}$

School of Animal, Rural and Environmental Sciences, Nottingham Trent University, Brackenhurst Campus, Southwell, Nottinghamshire, NG25 0QF, UK.

* Corresponding author. Tel.: +44 (0) 1158485212

E-mail address: carol.hall@ntu.ac.uk (C. Hall)

${ }^{1}$ These authors contributed equally to the work.

\begin{abstract}
The assessment of ridden horse behavior by twelve equestrian professionals (riding instructors $\mathrm{n}=4$, riders $\mathrm{n}=4$, veterinary surgeons $\mathrm{n}=4$ ) was compared with observed behavior and physiological measures (salivary cortisol and eye temperature). Horses $(n=10)$ were ridden at walk, trot and canter in a pre-defined test of approximately 2-3 minutes. Video footage of the ridden test was analyzed using Observer XT 10 and duration of behavioral states/events recorded. Saliva was collected in the stable, after the warm up (WU) and at 0, 5, 15, 30 and 60 minutes post-ridden-test (RT). The saliva was analyzed for cortisol (enzyme-linked immunosorbent assay) and the difference between minimum and maximum concentration $(\mathrm{ng} / \mathrm{ml})$ and associated sample times recorded. Eye temperature was measured using an infrared thermal camera (MobIR® M8), using static images (stable, after WU, after RT), and video footage (WU and RT) with maximum eye temperatures derived from set intervals. Mean maximum eye temperatures during ridden work were calculated. Video footage of the ridden test was observed by the twelve equestrian professionals who each scored the horses on seven performance parameters derived from the Fédération Equestre Internationale (FEI) rules for dressage events and the training scale of the German National Equestrian Federation (relaxation, energy, compliance, suppleness, confidence, motivation and happiness). These scores were compared with behavioral and physiological measures and correlations investigated (Spearman's Rank Order Correlation). Higher percentage durations of high head carriage (ranging from 0$50.75 \%$ of RT) and the nose carried at an angle in front of the vertical (0-74.29\% of RT) correlated with overall less favorable assessment by the equestrian professionals $(\mathrm{p}<0.05)$ and
\end{abstract}


only the instructors associated neutral head carriage (32.76-91.92\% of RT) and vertical nasal angle $(0.97-68.90 \%$ of $\mathrm{RT})$ as a positive sign $(\mathrm{p}=0.03$ and $\mathrm{p}=0.04$ respectively). Increases in salivary cortisol positively correlated with the duration of low head carriage $(\mathrm{p}<0.05)$, suggesting that this way of going increased the demands placed on the horse. Increased eye temperature positively correlated with duration of nose carried behind the vertical when ridden $(\mathrm{p}=0.02)$ and negatively correlated with duration of nose carried in front of the vertical $(\mathrm{p}=0.01)$. Some discrepancy between physiological evidence and professional assessment of ridden horse behavior was evident as were differences between groups of professionals. Further evaluation of the association between behavioral signs and physiological measures is now required to ensure that the assessment of ridden horse performance is based on valid and consistent measures.

Keywords: horse, stress, ridden behavior, cortisol, eye temperature

\section{Introduction}

Ridden horse assessment is generally based on subjective judgment of observed behavior. In addition to physical soundness, veterinarians and other equestrian professionals need to be able to identify signs of mental distress in ridden horses (Ödberg, 1987), which can contribute to poor performance, health and behavioral problems. Within international equestrian sport there is much debate surrounding the stress associated with training methods, in particular in relation to head and neck position (van Breda, 2006; von Borstel et al., 2009; McGreevy et al., 2010). In response, the Fédération Equestre Internationale (FEI, 2009) published guidelines advocating harmonious education of the horse resulting in overt behavior indicative of 'submission' and the development of the horse into a 'happy athlete'. The guidelines state that the nasal plane should at all times be positioned in front of the vertical (FEI, 2009). However, there is evidence that over-flexion of the neck (and the consequent positioning of the nasal plane behind the vertical) is still considered by some as a positive sign in the ridden horse (McGreevy et al., 2010). For example, during official stallion performance tests higher scores for ride-ability were awarded to horses that were ridden with their nose-line predominantly behind the vertical, than to those 
ridden with their nose-line at the vertical (König von Borstel et al., 2011). Behavioral events such as grinding the teeth and agitation of the tail are considered to be signs of nervousness, tension or resistance on the part of the horse (FEI, 2009). In their judgment of ridden horse behavior, equestrian professionals will rely on overt behavioral signs, but the relative importance attributed to specific signs is unlikely to be consistent across professional disciplines. To determine whether the interpretation of behavioral signs used in such judgments is justifiable, more objective evidence is required.

In ridden work physiological measures of mental stress are confounded by the effect of the physical demands of exercise (Marlin and Nankervis, 2002), as well as problems in distinguishing between excitement / arousal and fear / anxiety. Factors such as fitness and age need to be taken into consideration if hormonal stress responses are to be used as a means of interpreting behavioral signs. However, in low level exercise scenarios findings suggest that anxiety-provoking situations produce increases in salivary cortisol concentration (Schmidt et al., 2010). Training per se affects baseline plasma cortisol concentration in riding horses (Fazio et al., 2006) and subsequent cortisol response to ridden events is affected by previous training (Fazio et al., 2008). With due consideration to such factors, salivary cortisol response to low levels of established ridden work may provide evidence of the demand characteristics of some aspects of ridden horse behavior.

Circulatory changes are a more immediate physiological response to sympathetic activation (preparing the animal for flight or fight) and are associated with changes in surface temperature. These can be measured using infrared thermography (IRT) and have been used as a non-invasive means of assessing stress responses in animals (Stewart et al., 2005). In particular, eye temperature has been shown to increase in some species in response to potentially distressing procedures (Cook et al., 2006; Stewart et al., 2007). In the horse increases in eye temperature were found to correlate with increases in salivary cortisol during a potentially aversive procedure (clipping) (Yarnell et al., 2013) and higher eye temperatures were recorded when horses were lunged in a training aid (Pessoa) than when lunged without (Hall et al., 2011). Eye temperature offers a means of confirming (or not) the interpretation of behavioral signs in the ridden horse The aim of this study was to compare the judgment of ridden horse behavior made by equestrian professionals with evidence from both observed behavior and physiological measures. 
Associations between scoring and the duration of observed behavior and between behavior and physiological responses were investigated. The long term aim is to identify behavioral signs in the ridden horse that are indicative of mental state.

\section{Materials and methods}

\section{Horses}

The study involved ten riding horses (six geldings, four mares) and ten experienced riders (who rode the horse regularly). Horse heights ranged from $158-173 \mathrm{~cm}$, their ages from 5-20 years (mean age 12.9 years) and they were thoroughbred and thoroughbred $\mathrm{x}$ warmblood cross in type. The current roles of the horses were either predominantly competitive $(n=6)$, leisure $(n=2)$ or riding school work $(n=2)$. All horses were in work at the time of the study (ridden 5 days/week) and were at levels of fitness befitting their current workload. This ranged from fit for regular hacking (walk, trot and canter) to competition fit (British Eventing novice level). The trial was carried out in the United Kingdom during July and the horses were field kept $(n=4)$, or on a combined stable / field turnout regime, stabled during the day $(n=2)$ or stabled overnight $(n=4)$.

\section{Experimental design}

Each horse/rider combination completed a ridden trial consisting of a warm-up (WU) and ridden test (RT). Behavior was recorded from the video footage of the RT and this footage was also assessed by equestrian professionals $(n=12)$. Physiological measures were taken throughout the trial (salivary cortisol and eye temperature). Handling behavior was scored at sampling sessions before and after the RT to assess the impact of the ridden work on general behavior. See Table 1 for details of the sampling times for each measure. The study was conducted in accordance with the Nottingham Trent University's ethical review process.

\section{Ridden trials}

The ridden trials were all conducted at the horses' home yards and ridden work took place outside between 10.30 and 15.00 hours. The horse was prepared for ridden work (normal tack with no martingales, draw reins or other schooling aids; four horses wore flash nosebands, the rest wore plain cavesson nosebands), led to the riding area, mounted and warmed up (WU) for 10-20 minutes (including work in walk, trot and canter on both reins). Each horse was ridden in a 
fenced arena on an all weather surface in an area of approximately $20 \times 40$ meters. No other horses were present during the trials. The ridden test (RT) consisted of set movements as described in Table 2.

Table 1: Sampling times for each measure taken during the study

\begin{tabular}{|c|c|c|c|c|c|}
\hline Measure & $\begin{array}{l}\text { Pre-ridden } \\
\text { work }\end{array}$ & $\begin{array}{c}\text { Warm-up } \\
\text { (WU) }\end{array}$ & $\begin{array}{c}\text { Post WU / } \\
\text { Pre RT }\end{array}$ & $\begin{array}{l}\text { Ridden test } \\
\text { (RT) }\end{array}$ & $\begin{array}{c}\text { Post-ridden } \\
\text { work }\end{array}$ \\
\hline $\begin{array}{l}\text { Ridden } \\
\text { behavior }\end{array}$ & & & & $\begin{array}{l}\% \text { duration of } \\
\text { behavior } \\
\text { recorded from } \\
\text { video }\end{array}$ & \\
\hline $\begin{array}{l}\text { Saliva } \\
\text { sampling } \\
\text { (cortisol) }\end{array}$ & $\begin{array}{l}\text { Sampled } \\
\text { before } \\
\text { preparation } \\
\text { for ridden } \\
\text { work }\end{array}$ & & $\begin{array}{l}\text { Sampled post } \\
\text { WU }\end{array}$ & & $\begin{array}{l}\text { Sampled } 0,5 \\
15,30 \text { and } 60 \\
\text { mins post RT }\end{array}$ \\
\hline $\begin{array}{l}\text { Eye } \\
\text { temperature } \\
\text { (static IRT) }\end{array}$ & $\begin{array}{l}\text { Maximum } \\
\text { eye } \\
\text { temperature } \\
\text { recorded }\end{array}$ & & $\begin{array}{l}\text { Maximum } \\
\text { eye } \\
\text { temperature } \\
\text { recorded }\end{array}$ & & $\begin{array}{l}\text { Maximum } \\
\text { eye } \\
\text { temperature } \\
\text { recorded } \\
(0,5,15,30 \\
\text { and } 60 \text { mins } \\
\text { post RT })\end{array}$ \\
\hline $\begin{array}{l}\text { Eye } \\
\text { temperature } \\
\text { (video IRT) }\end{array}$ & & $\begin{array}{l}\text { Maximum } \\
\text { eye } \\
\text { temperature } \\
\text { recorded at } 3 \\
\text { set points } \\
\text { during WU }\end{array}$ & & $\begin{array}{c}\text { Maximum } \\
\text { eye } \\
\text { temperature } \\
\text { recorded at } 7 \\
\text { set points } \\
\text { during RT }\end{array}$ & \\
\hline $\begin{array}{l}\text { Scoring by } \\
\text { professionals }\end{array}$ & & & & $\begin{array}{l}\text { RT videos } \\
\text { scored on } 7 \\
\text { parameters }\end{array}$ & \\
\hline $\begin{array}{l}\text { Handling } \\
\text { test }\end{array}$ & $\begin{array}{c}\text { Behavior } \\
\text { scored from } \\
\text { video }\end{array}$ & & & & $\begin{array}{c}\text { Behavior } \\
\text { scored from } \\
\text { video ( } 0 \text { and } \\
60 \text { mins post } \\
\text { RT) }\end{array}$ \\
\hline
\end{tabular}


Table 2: Ridden test

Pace Movements

TROT

1. Start half way down the long side facing the person filming, and begin by trotting down the long side towards them (working trot)

2. Carry on trotting through the next short side ${ }^{\mathrm{IRT}}$

3. Change the rein through the long diagonal, with a transition to and from walk in the centre of the arena (you should walk for approximately one horse's length) ${ }^{\text {IRT }}$

4. Continue around the short side of the arena

CANTER

5. Pick up canter anywhere on the short side (or in the corner) ${ }^{\text {IRT }}$

6. Proceed in working canter down the next long side and through the following short side

7. Change the rein through the long diagonal, with change of lead through trot in the centre. You should trot for two to four strides ${ }^{\text {RT }}$

8. Continue in working canter down the next long side until half way, then ride downwards transitions to trot ${ }^{\mathrm{IRT}}$ and walk

\section{WALK}

9. Continue in medium walk down the long side and through the next short side

10. Change the rein through the long diagonal, with a free walk on a long rein ${ }^{I R T}$

11. Return to medium walk at the end of the diagonal and continue through the short side

12. Ride a downwards transition to halt halfway through the short side ${ }^{\text {IRT }}$

${ }^{\mathrm{IRT}}$ denotes the points at which maximum eye temperature was recorded.

The RT was recorded with a Canon Legria FS306 digital video camera (hand held) positioned at one of the short sides of the arena. Recording began when the horse passed approximately halfway down the long side of the arena approaching the video camera and ceased when the horse came to a halt at the end of the test. The person filming the ridden test directed the camera to follow the horse around to keep it centered in the video.

\section{Behavior during ridden test}

The video footage (RT) was analyzed using Observer XT 10 behavioral analysis software. See Table 3 for a list of behavioral categories, associated states and descriptors (adapted from Weeks, 
1996; Kaiser et al., 2006; Heleski et al., 2009; Hall et al., 2012). The duration of each behavioral state for each separate category was calculated using Observer XT 10 as a percentage of the duration of the ridden test for each horse. When specific behaviors were not visible this was recorded to evaluate relative visibility.

Table 3: Behavior recorded during ridden test with descriptors.

\begin{tabular}{|c|c|c|}
\hline $\begin{array}{l}\text { Behavioral } \\
\text { category }\end{array}$ & $\begin{array}{l}\text { Variation of } \\
\text { behavior } \\
\text { within } \\
\text { category }\end{array}$ & Description of behavioral variations \\
\hline \multirow{3}{*}{$\begin{array}{l}\text { Head position / } \\
\text { nasal plane }\end{array}$} & Vertical & Nasal plane approximately vertical \\
\hline & Behind vertical & Nasal plane at least 10 degrees behind the vertical \\
\hline & $\begin{array}{l}\text { In front of } \\
\text { vertical }\end{array}$ & Nasal plane at least 10 degrees in front of the vertical \\
\hline \multirow[t]{3}{*}{ Head/neck carriage } & High & Nose above the withers \\
\hline & Neutral & Nose between withers and abdominal line \\
\hline & Low & Nose below abdominal line \\
\hline \multirow[t]{7}{*}{ Head movement } & Still central & $\begin{array}{l}\text { Absence of lateral cervical flexion, head in line with } \\
\text { rest of horse's body }\end{array}$ \\
\hline & $\begin{array}{l}\text { Still turned to } \\
\text { left }\end{array}$ & $\begin{array}{l}\text { Lateral cervical flexion to the left, not in line with rest } \\
\text { of horse's body }\end{array}$ \\
\hline & $\begin{array}{l}\text { Still turned to } \\
\text { right }\end{array}$ & $\begin{array}{l}\text { Lateral cervical flexion to the right, not in line with } \\
\text { rest of horse's body }\end{array}$ \\
\hline & Still tilted left & $\begin{array}{l}\text { Nasal midline not perpendicular to ground; deviation } \\
\text { of angle of nasal midline to left }\end{array}$ \\
\hline & Still tilted right & $\begin{array}{l}\text { Nasal midline not perpendicular to ground; deviation } \\
\text { of angle of nasal midline to right }\end{array}$ \\
\hline & $\begin{array}{l}\text { Tossing } \\
\text { vertically }\end{array}$ & $\begin{array}{l}\text { The horse moves the head in a quick forward-upward } \\
\text { motion }\end{array}$ \\
\hline & $\begin{array}{l}\text { Tossing } \\
\text { laterally }\end{array}$ & The horse moves the head in a quick lateral motion \\
\hline \multirow[t]{2}{*}{ Ear position } & Both forward & Both ears immobile with pinna pointed forward \\
\hline & $\begin{array}{l}\text { Both back } \\
\text { relaxed }\end{array}$ & Both ears turned backward without being flattened \\
\hline
\end{tabular}




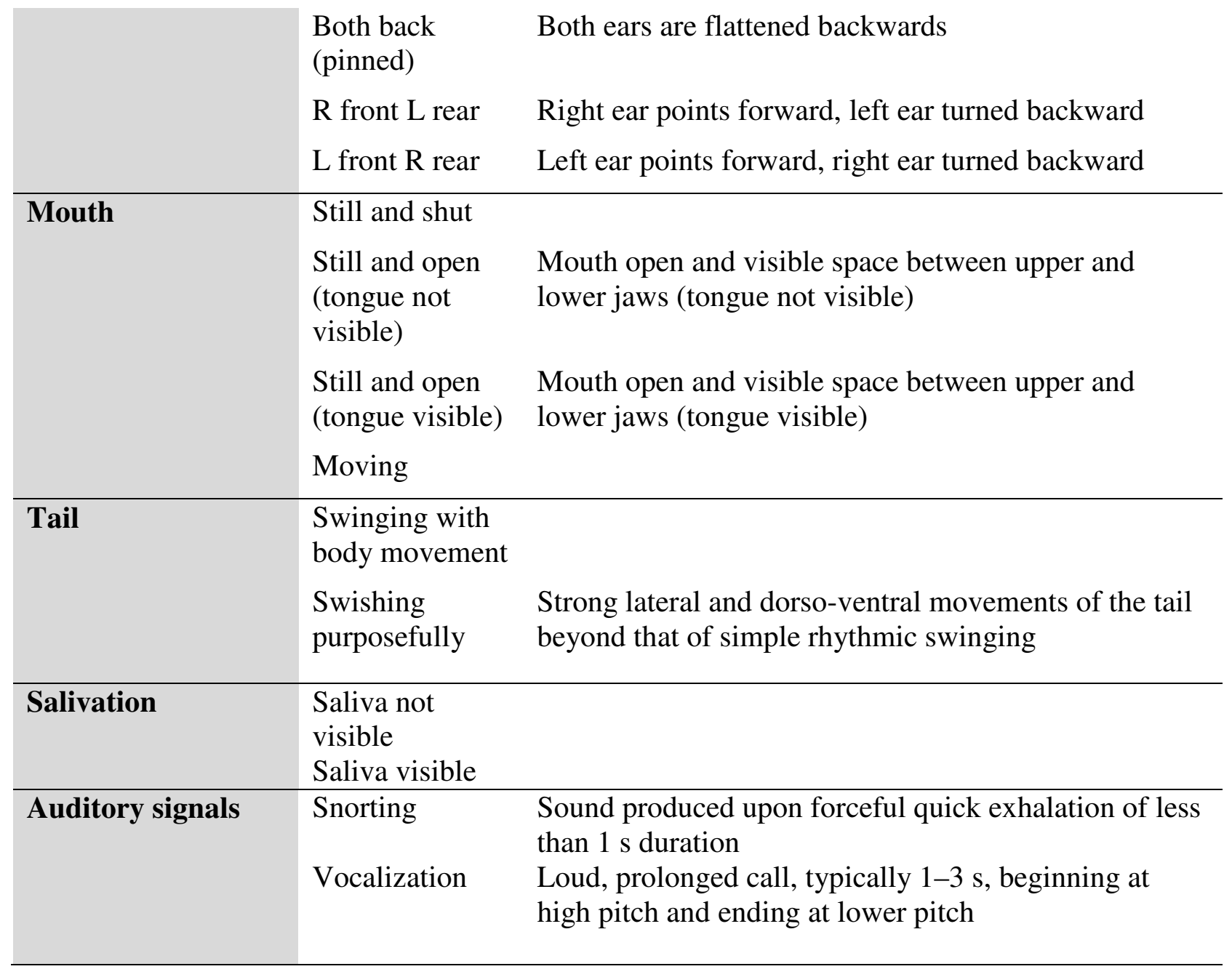

\section{Physiological measures}

\section{Saliva collection and cortisol analysis}

Saliva was collected using salivettes ${ }^{\circledR}$ (Sarstedt, UK) designed for human use and modified by the addition of a cotton thread to enable the human handler to keep hold of the salivette ${ }^{\circledR}$ while the horse chewed. The swab was placed in the horse's oral cavity at the height of the third premolar in the maxilla for approximately 30 seconds. Salivettes@ were refrigerated at $4{ }^{\circ} \mathrm{C}$ for no longer than two hours before they were transferred and frozen at $-20{ }^{\circ} \mathrm{C}$ until analysis. The saliva was analyzed for cortisol using a commercially available Enzyme-linked immunosorbent assay (ELISA, DRG Diagnostics). A total of two salivary cortisol assays were carried out for this study. The $\%$ coefficient of variation of means for high control was $3.93 \%$ and the coefficient of 
variation of means for low control was 7.36\%. The mean inter-assay coefficient of variation was $5.65 \%$. Cortisol concentration was calculated for each horse / sample time (ng/ml).

\section{Eye temperature}

Eye temperature throughout the study was recorded using a MobIR ${ }^{\circledR}$ M8 thermal camera (Wuhan Guide Infrared Company Ltd., China). Ambient temperature was recorded at each sampling time. Static thermal images from both left and right eye were captured at a distance of 1 meter \pm 50 centimeters from the horse at a 90 degree angle immediately prior to saliva sampling. Images were uploaded to analytical software (Guide IrAnalyser) and the maximum temperature for the eye (from within the palpebral fissure around the entire eyelid margin from the lateral commissure to the lacrimal caruncle) recorded. No significant difference between right and left eye temperatures was found and mean maximum eye temperature $\left({ }^{\circ} \mathrm{C}\right)$ was calculated for each horse/sample time (stable, post WU, post RT) for subsequent analyses.

During WU and RT video footage was collected using the same MobIR® M8 thermal camera with added $30 \mathrm{~mm}$ Tele lens, hand held adjacent to the position of the video camera. The footage was uploaded to the Guide IrAnalyser software and eye temperature (from the visible eye only) was extracted as for the static images. Maximum eye temperature was recorded at three points within WU (start; after one minute; after five minutes). Maximum eye temperature was recorded in RT at seven set points (identified by IRT in Table 2). Mean values were calculated for WU and RT.

\section{Professional judgment}

The video footage of the ridden test was assessed by twelve professionals, all of whom had ridden / trained horses for at least ten years and whose primary role was described as either veterinary surgeon $(n=4)$, riding instructor $(n=4)$ or rider $(n=4)$. These professionals were recruited from staff associated with the university and from nearby veterinary and academic institutions. The order in which the horses were viewed was different for each participant. The clips were played back on a PC / laptop and after watching each individual clip the horse was assessed on seven parameters, on a scale of 1-5. These parameters (see Table 4) were derived from the FEI Rules for Dressage Events (FEI, 2009) and the training scale of the German National Equestrian Federation (1997). 
Mean scores were calculated for each horse (for each parameter and overall), from all scorers together and also separately from veterinary surgeons, instructors and riders.

Table 4: The parameters used for subjective evaluation of the horse in the ridden test and related scales (adapted from the scales of training of the German National Equestrian Federation, 1997 and the FEI Rules for Dressage Events, 2009).

\begin{tabular}{|c|c|c|c|c|c|}
\hline Parameter & Score 1 & Score 2 & Score 3 & Score 4 & Score 5 \\
\hline Relaxation & Very relaxed & Quite relaxed & $\begin{array}{l}\text { Neither } \\
\text { relaxed nor } \\
\text { tense }\end{array}$ & Quite tense & Very tense \\
\hline Energy & $\begin{array}{c}\text { Very } \\
\text { energetic }\end{array}$ & $\begin{array}{c}\text { Quite } \\
\text { energetic }\end{array}$ & $\begin{array}{c}\text { Neither } \\
\text { energetic nor } \\
\text { lethargic }\end{array}$ & $\begin{array}{c}\text { Quite } \\
\text { lethargic }\end{array}$ & Very lethargic \\
\hline Compliance & $\begin{array}{c}\text { Very } \\
\text { compliant }\end{array}$ & $\begin{array}{l}\text { Quite } \\
\text { compliant }\end{array}$ & $\begin{array}{l}\text { Neither } \\
\text { compliant nor } \\
\text { resistant }\end{array}$ & $\begin{array}{l}\text { Quite } \\
\text { resistant }\end{array}$ & Very resistant \\
\hline Suppleness & Very supple & Quite supple & $\begin{array}{l}\text { Neither } \\
\text { supple nor } \\
\text { stiff }\end{array}$ & Quite stiff & Very stiff \\
\hline Confidence & $\begin{array}{c}\text { Very } \\
\text { confident }\end{array}$ & $\begin{array}{c}\text { Quite } \\
\text { confident }\end{array}$ & $\begin{array}{l}\text { Neither } \\
\text { confident nor } \\
\text { timid }\end{array}$ & Quite timid & Very timid \\
\hline Motivation & $\begin{array}{c}\text { Very } \\
\text { motivated }\end{array}$ & $\begin{array}{c}\text { Quite } \\
\text { motivated }\end{array}$ & $\begin{array}{c}\text { Neither } \\
\text { motivated nor } \\
\text { unmotivated }\end{array}$ & $\begin{array}{c}\text { Quite } \\
\text { unmotivated }\end{array}$ & $\begin{array}{c}\text { Very } \\
\text { unmotivated }\end{array}$ \\
\hline Happiness & Very happy & Quite happy & $\begin{array}{l}\text { Neither happy } \\
\text { nor unhappy }\end{array}$ & $\begin{array}{c}\text { Quite } \\
\text { unhappy }\end{array}$ & Very unhappy \\
\hline
\end{tabular}

\section{Handling test}

The behavior of each horse was recorded at each saliva collection sampling time using a Canon Legria FS306 digital video camera. The camera was hand held and the operator was located at a distance of approximately 4 meters from the horse. Video footage was uploaded onto a laptop computer and viewed using Windows media player. Video clips from three sampling times (the initial sampling time pre-ridden test, immediately after the ridden test and 60 minutes after the ridden test) were used to score signs of relaxation / anxiety in each horse and the potential effect of the ridden test on general anxiety level. Each video clip was numbered (1-30) to allow 
identification of horse and stage of trial but then arranged in a random order for scoring purposes. The scoring scale used and a description of the behavior associated with each score is shown in Table 5.

The 30 video clips were viewed and scored by 20 undergraduate students on an equine degree course and their tutor. Inter-observer variability was calculated (Cronbach's Alpha) to assess the reliability of the scoring. Mean behavior scores were then calculated for each horse / sample time combination.

Table 5: Scale used to assess level of relaxation (activity level) relating to response to procedure and behaviors associated with each score.

\begin{tabular}{cll}
\hline Score & Type of Response & Associated behaviors \\
\hline $\mathbf{1}$ & Very relaxed & $\begin{array}{l}\text { No movement apart from mouth, minimal ear movement. No attempt } \\
\text { to avoid procedure. }\end{array}$ \\
$\mathbf{2}$ & $\begin{array}{l}\text { Quite relaxed } \\
\text { Alert / interested }\end{array}$ & $\begin{array}{l}\text { Slow movements of head / ears. No attempt to avoid procedure. } \\
\text { Ears forward. Head raised. Looking towards handler / procedure. } \\
\text { Interest but no attempt to avoid. }\end{array}$ \\
$\mathbf{3}$ & Anxious & $\begin{array}{l}\text { Head and neck moving away. Ears back / moving rapidly. No body } \\
\text { movement. Initial attempt to avoid procedure. } \\
\text { Movement of head, neck and body. Abrupt movement away. } \\
\text { Repeated attempts to avoid procedure. }\end{array}$ \\
\hline $\mathbf{5}$ & $\begin{array}{l}\text { Frightened / } \\
\text { avoidance }\end{array}$ & . \\
\hline
\end{tabular}

\section{Data analyses}

All statistical analyses were carried out using IBM SPSS 19.

Non-parametric analyses were used throughout as the majority of data sets varied significantly from the normal distribution (Kolmogorov-Smirnov test: $\mathrm{p}<0.05$ ).

The overall effect of sample time on salivary cortisol concentration, eye temperature and behavior during handling was assessed (Friedman Test; Wilcoxon Signed Rank Test). The effect of gender, housing, noseband type and current role on these measures was tested (Mann-Whitney U Test; Kruskal-Wallis Test) as was their correlation with the age of the horse (Spearman Rank Order Correlation). 
To assess the impact of the ridden work on cortisol concentration, sample times associated with maximum and minimum concentration values were identified for each horse and the difference between them calculated for each horse for comparison with professional judgment, eye temperature and behavioral data. Mean maximum eye temperatures were calculated for both static images (stable, post WU and post RT) and video (WU and RT). Correlations between cortisol, eye temperature and the percentage durations of observed ridden behavior were assessed (Spearman Rank Order Correlation).

Mean performance scores awarded for the ridden test by the professionals were calculated for each parameter (see Table 4) and overall. Mean scores awarded by each group of professionals were calculated separately to enable the comparison of the assessment by the different groups (Spearman Rank Order Correlation). Correlation between these scores, recorded behavior, salivary cortisol and eye temperature was assessed (Spearman Rank Order Correlation).

In the handling test the effect of sample time on mean behavior scores was assessed (Friedman test) as was the correlation between mean maximum eye temperature and mean behavior score (Spearman Rank Order Correlation).

\section{Results}

\section{Salivary cortisol}

The cortisol response of individual horses varied and there was no consistent effect of sample time on cortisol concentration. However, some horses $(n=5)$ had minimum cortisol concentration at 15 minutes post ridden test and maximum at either the initial sample time (stable: $n=3$ ), 60 minutes post ridden test $(n=1)$ or immediately before the ridden test $(n=1)$. These horses showed a reduction in cortisol concentration associated with the ridden work, whileothers $(n=5)$ had an increase in cortisol concentration in response to ridden work (of varying amounts and at slightly differing times). In the horses showing a decrease one horse (horse 7) was recorded as having maximum cortisol concentration $(9.42 \mathrm{ng} / \mathrm{ml}) 60$ minutes post RT. This horse was observed performing stereotypical behavior and was not included in subsequent correlations with other measures. When this horse was discounted a significant effect of sample time on cortisol concentration was found for the other four horses showing a drop in cortisol concentration (Friedman test: $\left.X^{2}(6, n=4)=13.143, p=0.041\right)$. This effect was still apparent when all five 
horses were included but the last sample time (60mins post RT) was excluded (Friedman test: $\mathrm{X}^{2}$ $(5, \mathrm{n}=5)=13.506, \mathrm{p}=0.19)$. Cortisol concentration was found to be significantly lower (mean $1.29 \pm 0.12 \mathrm{ng} / \mathrm{ml}) 15$ minutes post RT than at any other sample time $(\mathrm{p}<0.05)$. No significant effect of sample time was found for the horses showing increased cortisol concentration associated with the RT. Minimum cortisol concentrations occurred either at the initial sample time (stable: $\mathrm{n}=2), 60$ minutes post ridden test $(\mathrm{n}=1)$, immediately $(\mathrm{n}=1)$ or 5 minutes post ridden test $(n=1)$. Maximum cortisol concentrations were found at either $5(n=3)$ or $30(n=2)$ minutes post ridden test. The mean cortisol responses of both groups are shown in Figure 1. The cortisol response of each horse is shown in Table 6. A positive correlation between baseline cortisol concentration and the age of the horse was found ( $r h o=0.644, \mathrm{n}=10, \mathrm{p}=0.044$ ) and there was a tendency for younger horses to show a greater increase although this was not significant (rho=$0.564, \mathrm{n}=10, \mathrm{p}=0.084)$. No other factor was found to affect cortisol concentration.

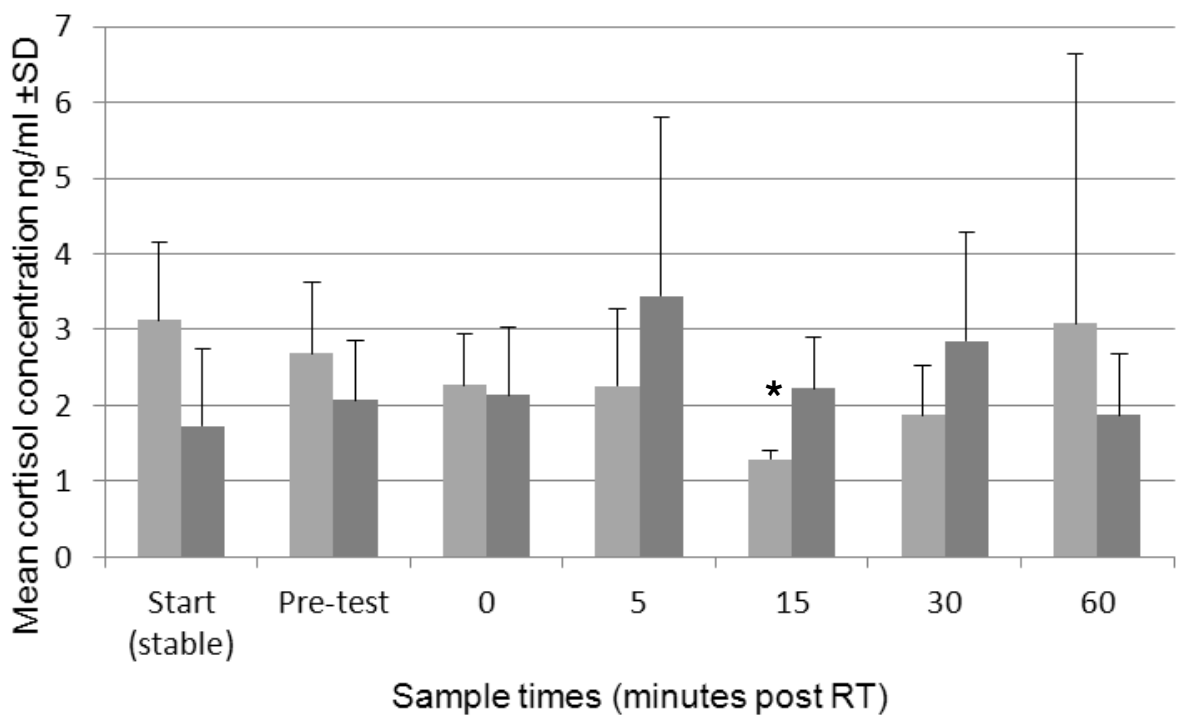

- Horses with decrease in salivary cortisol concentration in relation to RT

- Horses with increase in salivary cortisol concentration in relation to RT

Figure 1:Mean cortisol concentration at each sample time for the five horses $(H 1,2,5,7,8)$ that had a relative decrease in cortisol concentration with minimum concentration at 15 minutes post ridden test (significantly lower than at any other sample time $p<0.05$ as signified by *) and for the five horses $(\mathrm{H} 3,4,6,9,10)$ that had varying levels of increase in cortisol concentration following the ridden test (but no significant effect of sample time was found for this group) $( \pm S D)$. 
Table 6: Physiological responses, behavior (shown as \% time in each) and professional assessment of individual horses in the ridden test

\begin{tabular}{|c|c|c|c|c|c|c|c|c|c|c|}
\hline $\begin{array}{c}\text { Horse } \\
\text { number }\end{array}$ & 1 & 2 & 3 & 4 & 5 & 6 & 7 & 8 & 9 & 10 \\
\hline $\begin{array}{c}\text { Change in } \\
\text { salivary } \\
\text { cortisol } \\
\text { concentration } \\
\mathrm{ng} / \mathrm{ml}\end{array}$ & -2.43 & -1.45 & +1.24 & +1.37 & -1.91 & +4.12 & -8.11 & -3.31 & +3.95 & +5.43 \\
\hline $\begin{array}{c}\text { Mean } \\
\text { maximum eye } \\
\text { temperature } \\
{ }^{\circ} \mathrm{C} \pm \mathrm{SD}\end{array}$ & $\begin{array}{l}27.26 \\
\pm 1.11\end{array}$ & $\begin{array}{l}26.26 \\
\pm 1.62\end{array}$ & $\begin{array}{l}26.21 \\
\pm 0.95\end{array}$ & $\begin{array}{l}29.94 \\
\pm 1.75\end{array}$ & $\begin{array}{r}28.08 \\
\pm 1.47\end{array}$ & $\begin{array}{l}27.22 \\
\pm 2.43\end{array}$ & $\begin{array}{l}29.66 \\
\pm 2.55\end{array}$ & $\begin{array}{l}28.79 \\
\pm 1.81\end{array}$ & $\begin{array}{l}29.35 \\
\pm 2.48\end{array}$ & $\begin{array}{l}33.41 \\
\pm 1.50\end{array}$ \\
\hline $\begin{array}{l}\text { Head/ neck } \\
\text { high }\end{array}$ & 5.93 & 50.75 & 0 & 0.95 & 14.7 & 0 & 0 & 8.16 & 0 & 0 \\
\hline $\begin{array}{c}\text { Head/neck } \\
\text { neutral }\end{array}$ & 79.66 & 32.76 & 66.28 & 77.34 & 70.34 & 91.92 & 82.24 & 77.39 & 66.34 & 73.81 \\
\hline $\begin{array}{l}\text { Head/neck } \\
\text { low }^{1}\end{array}$ & 0 & 0 & 14.62 & 0 & 0 & 1.10 & 0 & 0 & 9.76 & 14.36 \\
\hline $\begin{array}{l}\text { Nasal plane } \\
\text { vertical }\end{array}$ & 20.90 & 7.40 & 20.18 & 48.50 & 17.50 & 24.67 & 54.6 & 68.9 & 0.97 & 16.19 \\
\hline $\begin{array}{l}\text { Nasal plane } \\
\text { behind } \\
\text { vertical }^{2 \mathrm{a}}\end{array}$ & 2.32 & 0 & 0 & 0.44 & 0 & 0 & 0.19 & 0 & 55.44 & 45.30 \\
\hline $\begin{array}{l}\text { Nasal plane } \\
\text { in front of } \\
\text { vertical }^{2 b}\end{array}$ & 55.82 & 74.29 & 57.09 & 13.31 & 61.34 & 36.63 & 24.50 & 10.04 & 0 & 1.67 \\
\hline $\begin{array}{c}\text { Mean score } \\
\text { (vets) } \pm \text { SD }\end{array}$ & $\begin{array}{c}2.61 \\
\pm 0.57\end{array}$ & $\begin{array}{c}3.29 \\
\pm 0.60\end{array}$ & $\begin{array}{c}2.75 \\
\pm 0.22\end{array}$ & $\begin{array}{c}3.07 \\
\pm 0.69\end{array}$ & $\begin{array}{c}3.11 \\
\pm 0.30\end{array}$ & $\begin{array}{c}2.36 \\
\pm 0.83\end{array}$ & $\begin{array}{c}2.29 \\
\pm 0.17\end{array}$ & $\begin{array}{c}2.32 \\
\pm 0.56\end{array}$ & $\begin{array}{c}2.36 \\
\pm 0.25\end{array}$ & $\begin{array}{c}2.32 \\
\pm 0.76\end{array}$ \\
\hline $\begin{array}{c}\text { Mean score } \\
\text { (instructors) } \\
\quad \pm \text { SD }\end{array}$ & $\begin{array}{c}3.14 \\
\pm 0.31\end{array}$ & $\begin{array}{c}3.36 \\
\pm 0.54\end{array}$ & $\begin{array}{c}2.97 \\
\pm 0.46\end{array}$ & $\begin{array}{c}3.22 \\
\pm 0.34\end{array}$ & $\begin{array}{c}3.25 \\
\pm 0.62\end{array}$ & $\begin{array}{c}2.61 \\
\pm 1.21\end{array}$ & $\begin{array}{c}2.89 \\
\pm 0.52\end{array}$ & $\begin{array}{c}2.61 \\
\pm 0.58\end{array}$ & $\begin{array}{c}3.58 \\
\pm 0.63\end{array}$ & $\begin{array}{c}2.68 \\
\pm 0.82\end{array}$ \\
\hline $\begin{array}{l}\text { Mean score } \\
\text { (riders) } \pm \text { SD }\end{array}$ & $\begin{array}{c}3.11 \\
\pm 0.52\end{array}$ & $\begin{array}{c}3.07 \\
\pm 0.34\end{array}$ & $\begin{array}{c}3.04 \\
\pm 0.39\end{array}$ & $\begin{array}{c}3.25 \\
\pm 0.43\end{array}$ & $\begin{array}{c}3.47 \\
\pm 0.71\end{array}$ & $\begin{array}{c}2.57 \\
\pm 0.51\end{array}$ & $\begin{array}{c}2.54 \\
\pm 0.48\end{array}$ & $\begin{array}{c}2.79 \\
\pm 0.53\end{array}$ & $\begin{array}{c}2.29 \\
\pm 0.47\end{array}$ & $\begin{array}{c}2.36 \\
\pm 0.50\end{array}$ \\
\hline
\end{tabular}


${ }^{1}$ Denotes behavioral state where a significant positive correlation with changes in salivary cortisol concentration was found $(p<0.05)$.

${ }^{2}$ Denotes behavioral state where a significant correlation with eye temperature was found, positive $\left(^{a}\right)$ or negative $\left({ }^{b}\right)(p<0.05)$.

${ }^{3}$ The higher the score, the more negative the assessment (see Table 4).

\section{Eye temperature}

\section{Static images}

Eye temperatures in the stable were significantly higher (mean $32.44 \pm 2.96{ }^{\circ} \mathrm{C}$ ) compared with those recorded immediately after WU (mean $30.06 \pm 3.13{ }^{\circ} \mathrm{C}$ ), and immediately after RT (mean $30.56 \pm 3.04^{\circ} \mathrm{C}$ ) (Wilcoxon test: $\mathrm{z}=-2.65, \mathrm{p}=0.008 ; \mathrm{z}=-2.4, \mathrm{p}=0.017$ respectively). No significant difference between eye temperature recorded immediately after WU and after RT was found. There was a mean decrease in maximum eye temperature between the stable and the end of WU $\left(-2.38 \pm 1.99^{\circ} \mathrm{C}\right)$ and a slight subsequent increase after RT $\left(+0.50 \pm 1.37^{\circ} \mathrm{C}\right)$. Only Horse 5 had a decrease in eye temperature $\left(-2.75^{\circ} \mathrm{C}\right)$ between the end of WU and end of RT.

\section{Video images}

There was no difference in mean maximum eye temperature in WU and RT (video) (WU: 28.78 $\pm 2.32{ }^{\circ} \mathrm{C}$, RT: $28.40 \pm 2.06^{\circ} \mathrm{C}$ ). The temperatures obtained from the video footage were lower than those recorded immediately after WU and RT using static images, but a positive correlation was found between the RT video footage and static images taken immediately after WU (0 minutes pre-RT) $(\mathrm{rho}=0.709, \mathrm{n}=10, \mathrm{p}=0.022)$, and $\mathrm{RT}$ video footage and static images taken immediately after RT (rho=0.891, $\mathrm{n}=10, \mathrm{p}=0.001)$. Correlation between WU video footage and static images taken immediately after WU was found but this was not significant (rho=0.612, $\mathrm{n}=10, \mathrm{p}=0.06)$.

A significant increase in eye temperature occurred during WU (Friedman test: $X^{2}(2, n=10)$ $=8.60, \mathrm{p}=0.014)$. A significantly lower maximum eye temperature was recorded at the start $\left(27.66 \pm 2.77^{\circ} \mathrm{C}\right)$ than at after one minute during WU $\left(29.65 \pm 2.39{ }^{\circ} \mathrm{C}\right.$; Wilcoxon test: $\mathrm{z}=-2.803$, $\mathrm{p}=0.005)$. No difference in eye temperature occurred during RT. 
No correlation between ambient temperature and eye temperature was found, apart from immediately after RT (static images) when higher ambient temperature correlated with lower eye temperatures $(\mathrm{rho}=-0.869, \mathrm{n}=10, \mathrm{p}=0.001)$. No correlation between mean maximum eye temperature (static or video) and salivary cortisol concentration was found, but the horse with the greatest increase in cortisol also had the highest eye temperature. See Table 6. No effect of gender, housing, noseband, role or age on eye temperature was found.

\section{Association between ridden behavior and physiological measures}

The only significant correlations between physiological measures and behavior related to head and neck position. There was a positive correlation between duration of low head carriage and increased salivary cortisol concentration $(\mathrm{rho}=0.676, \mathrm{n}=9, \mathrm{p}=0.046)$. Higher eye temperatures were found to correlate with increased duration of nasal plane behind the vertical in RT both during (video: rho=0.731, $\mathrm{n}=10, \mathrm{p}=0.016$ ) and immediately after $\mathrm{RT}$ (static: rho=0.679, $\mathrm{n}=10$, $\mathrm{P}=0.031$ ). Lower eye temperatures were correlated with increased duration of nasal plane in front of the vertical in RT both during(video: $r h o=-0.806, \mathrm{n}=10, \mathrm{p}=0.005$ ) and immediately after RT (static: rho=-0.879, $\mathrm{p}=0.001$ ). Although no correlation between tail swishing and cortisol or eye

temperature was found, the two horses (Horses 6 and 10) with the greatest increase in salivary cortisol spent over $50 \%$ of the RT in this activity. See Table 6. Only one other horse tail swished for as long.

Non-visibility of different behaviors varied (Friedman test: $\mathrm{X}^{2}(5, \mathrm{n}=10)=39.6, \mathrm{p}<0.001$ ). Behavioral categories arranged in order of visibility (with mean \pm standard deviation $\%$ duration non-visible): tail movement $(1.21 \pm 2.24 \%)$; head / neck carriage (16.16 $\pm 4.86 \%)$; head movement (20.91 $\pm 3.29 \%)$; mouth (28.03 $\pm 5.55 \%)$, head position / angle of nasal plane (28.25 $\pm 9.66)$, ears $(56.87 \pm 27.4 \%)$. Differences in visibility for all categories, apart from between mouth and head position / angle of nasal plane, were significant $(\mathrm{p}<0.05)$.

\section{Professional judgment}

No correlation between the overall mean scores, or scores for individual parameters and cortisol or mean eye temperature was found. However, certain behavioural states were found to correlate with these scores. See Table 5. The longer the duration of high head / neck carriage, the more negative the overall evaluation ( $\mathrm{rho}=0.679, \mathrm{n}=10, \mathrm{p}=0.031$ ). When the mean scores for individual 
parameters (as shown in Table 4) were assessed the following was found. Duration of head high carriage was positively correlated with lack of motivation ( $r h o=0.949, n=10, p<0.001$ ) as was the duration of ears in a relaxed backward position $(\mathrm{rho}=0.720, \mathrm{n}=10, \mathrm{p}=0.019)$. Low head carriage was associated with increased motivated $(r h o=-0.643, n=10, p=0.045)$. Horses were judged to be more confident when their head was still for a higher percentage of the time (rho=-0.644, $\mathrm{n}=10$, $\mathrm{p}=0.044$ ), and more energetic when their nasal plane was behind the vertical for longer (rho=$0.779, \mathrm{n}=10, \mathrm{p}=0.008$ ). Horses were judged to be less supple the longer their nasal plane was in front of the vertical $(\mathrm{rho}=0.756, \mathrm{n}=10, \mathrm{p}=0.011)$ and more resistant the longer they had their left ear forward and right ear back ( $\mathrm{rho}=0.634, \mathrm{n}=10, \mathrm{p}=0.049)$. A summary of behaviour that was found to have positive or negative associations with physiological measures and with assessment by equine professionals is shown in Table 7.

Table 7: A comparative summary of ridden horse behavior found to correlate with either physiological measures (cortisol and eye temperature) or professional scoring during the ridden test $(p<0.05)$.

\begin{tabular}{lll}
\hline & Physiological evidence & Professional assessment \\
\hline Negative indicators & Low head carriage & High head carriage \\
& Nasal plane behind vertical & $\begin{array}{l}\text { Ears back relaxed (motivation) } \\
\text { Left ear forward / right ear back }\end{array}$ \\
\hline \multirow{2}{*}{ Positive indicators } & Nasal plane in front of vertical & $\begin{array}{l}\text { Nasal plane behind the vertical } \\
\text { Low head carriage } \\
\end{array}$ \\
& & Head still \\
\hline
\end{tabular}

When scoring by the different professional groups was compared positive correlations between scoring by veterinary surgeons and instructors ( $\mathrm{rho}=0.685, \mathrm{n}=10, \mathrm{p}=0.029$ ) and between veterinary surgeons and riders $(\mathrm{rho}=0.758, \mathrm{n}=10, \mathrm{p}=0.011)$ were found, but there was no correlation between riders and instructors. Behavior found to be associated with scores by each group differed. The veterinary surgeons attributed poorer scores to the horses with a longer duration of high head carriage ( $\mathrm{rho}=0.64, \mathrm{n}=10, \mathrm{p}=0.046$ ), nasal plane in front of the vertical (rho=0.673, $\mathrm{n}=10, \mathrm{p}=0.033)$ and ears back $(\mathrm{rho}=0.791, \mathrm{n}=10, \mathrm{p}=0.006)$. The instructors attributed better scores to the horses with a longer duration of neutral head carriage ( $\mathrm{rho}=-0.685, \mathrm{n}=10$, 
$\mathrm{p}=0.029$ ), vertical nasal plane (rho=-0.648, $\mathrm{n}=10, \mathrm{p}=0.043$ ) and greater tail movement (rho=$0.673, \mathrm{n}=10, \mathrm{p}=0.033)$. They attribited poorer scores to horses with longer durations of ears back (rho=0.841, $\mathrm{n}=10, \mathrm{p}=0.002$ ). The riders attributed poorer scores to the horses with a longer duration of nasal plane in front of the vertical $(r h o=0.605, n=10, p=0.029)$. See Table 8 for a summary of these findings.

Table 8: Behavioural states associated with positive and negative evaluation by different equestrian professionals.

\begin{tabular}{llll}
\hline & Veterinary surgeons & \multicolumn{1}{c}{ Instructors } & \multicolumn{1}{c}{ Riders } \\
\hline Negative indicators & $\begin{array}{l}\text { High head carriage* } \\
\text { Nasal plane in front of } \\
\text { vertical* } \\
\text { Ears back** }\end{array}$ & Ears back** & $\begin{array}{l}\text { Nasal plane in front of } \\
\text { vertical* }^{* *}\end{array}$ \\
\hline Positive indicators & & $\begin{array}{l}\text { Neutral head carriage* } \\
\text { Vertical nasal plane* } \\
\text { Increased tail } \\
\text { movement* }\end{array}$ \\
\hline
\end{tabular}

Significance value: $*$ denotes $\mathrm{p}<0.05, * *$ denotes $\mathrm{p}<0.01$

\section{Handling test}

The Cronbach's Alpha value of 0.97 for reliability showed a high degree of inter-observer consistency in behavior scoring during the handling tests. No significant difference in handling behaviour was found in relation to sample time (stable at start / 0 minutes post ridden test / 60 minutes post ridden test). A significant positive correlation was found between mean maximum eye temperature (from the same sample times) and mean behavior score, higher eye temperatures being associated with more anxious behavior ( $\mathrm{rho}=0.794, \mathrm{n}=10, \mathrm{p}=0.006$ ). There was a positive correlation between age of horse and handling score, with younger horses showing greater anxiety (rho=-0.748, $\mathrm{n}=10, \mathrm{p}=0.013$ ). There was also a significant effect of current role on handling score $\left(\mathrm{X}^{2}=6.545, \mathrm{df}=2, \mathrm{p}=0.038\right)$, with competition horses scored as being significantly more anxious than leisure horses or riding school horses $(\mathrm{p}<0.05)$. 


\section{Discussion}

The assessment made by the equestrian professionals in this study was not in accord with the physiological evidence and there was some discrepancy between the different groups as to what behavior constituted a positive or negative indicator. All professionals (and veterinary surgeons in particular) deemed a high head carriage and the nasal plane being in front of the vertical to be negative signs. However, the instructors scored neutral head carriage and vertical nasal plane as positive indicators. This lack of agreement between equestrian professionals is likely to be the result of assessing ridden horses for different purposes. While instructors and riders will generally be looking to improve ridden behavior, veterinary surgeons will be assessing soundness and other health parameters. In the study by König von Borstel et al. (2011) where ride-ability was judged to be better when the horse predominantly carried its nose behind the vertical, the assessment was carried out by riders rather than by judges on the ground. The latter study was conducted in Germany and may reflect international differences in equestrianism, However, the riders in the current study also appeared to consider the position of the nasal plane in front of the vertical to be a negative sign, even when observing the horse from 'the ground'. These findings provide further evidence of departure from the guidelines provided by the FEI stating that the nasal plane should at all times be positioned in front of the vertical (FEI, 2009).

The cortisol response to this ridden test varied with horses showing peaks that appeared to relate specifically to the ridden work at varying times. As noted earlier, cortisol levels vary with training and level of fitness, as well as the physical demands of the activity (Marlin and Nankervis, 2002; Fazio et al., 2006).The positive association found between increased cortisol and duration of low head carriage indicates that this position is more physically demanding than neutral or high head carriage. This effect is comparable to the increases in eye temperature found in horses lunged in a training aid (Pessoa) (Hall et al., 2011). The horse with the greatest increase in cortisol (that appeared to relate to the ridden test) was 'novice eventing fit' at the time of the study. This response may be indicative of anxiety, as shown by Schmidt et al. (2010). All five horses that had decreases in cortisol had minimum values at 15 minutes after the ridden test, suggesting increased relaxation. The positive effect of exercise on stabled horses has been demonstrated in the past (Freire et al., 2009) but in the current study no horse was stabled continuously. We found a positive correlation between age and baseline cortisol concentration 
but no link between cortisol and housing or current ridden role. It is possible that salivary cortisol analysis can provide an insight into the link between ridden behavior and physical and/or mental stress but fitness and past experience must first be taken into account.

More immediate measures of stress can be made using surface temperature changes associated with re-directed blood flow (Stewart et al., 2007). Increases in eye temperature have previously been shown to relate to stress responses in ridden horses (Valera et al., 2012). In the current study the horse with the greatest cortisol increase also had the highest eye temperature, which unlike the other horses tested, increased in the ridden work compared to the stable. In other species anxiety / fear responses have been associated with surface temperature changes of $<0.2^{\circ}$ C (humans: Ekman et al., 1983; rhesus monkeys: Nakayama et al., 2005). The eye area of the horse is surrounded by hair which may have affected the temperature readings. Also, the thermal camera used in this study was not sensitive enough to reliably record such subtle changes in temperature and further work is needed to confirm the precise nature of surface temperature changes in the horse before conclusions can be confidently drawn.

Correlations between specific behaviors and physiological measures provide some insight into the impact of aspects of ridden work. Increased eye temperature was found to correlate with increased time spent with the head being carried with the angle of the nasal plane behind the vertical. This correlation could have been an artifact of the angle at which the video thermal image was taken but was also found with eye temperatures taken from static images immediately after the ridden work. Carrying the head at an angle behind the vertical could relate to increased anxiety and/or reduced vision (McGreevy et al., 2010). The related increases in eye temperature provide further evidence of the potential negative impact of this particular head carriage in the ridden horse. The eye temperatures gathered using static images were higher than those obtained from a greater distance using video, but correlation between the two indicates that although actual temperatures may not be accurate, relative values were consistent. Validation of this technology is required before it can be reliably used to interpret behavior but further investigation is warranted.

The relative visibility of certain aspects of ridden behavior varied with tail movement being most visible. Agitation of the tail is identified by the FEI (2009) as a sign of nervousness, tension or resistance and the two horses that had RT-related cortisol increases spent over $50 \%$ of the time 
tail swishing. Other more subtle signs such as grinding the teeth (FEI, 2009) were less visible. More conclusive associations may be apparent if a continuous more comprehensive behavioral recording system could be developed. Further identification of behavioral signs based on objective measures is required to ensure that consistent and accurate judgment of ridden horse behavior can be made.

A positive correlation between eye temperature and anxiety-related handling behavior was found. In this part of the study the observers were provided with guidance on what behavior to look for when scoring each horse and this resulted in a high degree of inter-observer agreement. The guidelines provided by the FEI (2009) on aspects of ridden horse behavior that are positive or negative indictors were at least in part substantiated by the physiological measures taken in the current study. No specific guidelines were provided for the ridden horse assessment by equestrian professionals and only the instructors were found to make judgments that agreed in part with FEI guidelines (FEI, 2009). See Table 8. It should be noted that the distinction made between tail swishing and tail swinging was not always clear and although this behavior was found to be most visible, it is still open to differences in interpretation.

Inconsistency between the scoring of the ridden behavior by the equestrian professionals may well have been the consequence of interpreting behavioral signs differently and the need for comprehensive, evidence-based guidelines for what ridden behavior is indicative of 'good' or 'poor' performance is clear. Such guidelines would allow the early identification of potential problems. Ridden behavior problems are highly prevalent, particularly in those animals used primarily for leisure purposes (Hockenhull and Creighton, 2013) and consequent wastage / euthanasia of horses could be minimized if warning signs were identified more accurately and responded to earlier. Poor ridden performance can result from underlying, often sub-clinical, health problems (Mitchell, 2001) and stress in ridden work can increase the risk of health issues such as Equine Gastric Ulcer syndrome (EGUS) (McClure et al., 2005). We are unlikely to achieve universal consensus on how to assess ridden horse behavior. However, we must continue to acquire further evidence to ensure consistent and valid interpretation of behavioral signs in ridden horses. 


\section{Conclusions}

Behavioral signs and physiological measures need further evaluation to ensure the accurate interpretation of ridden horse behavior and consequently reduce the occurrence of stress-related health and behavioral problems.

\section{Conflict of interest: none}

\section{Acknowledgements}

We would like to thank the riders who took part in this study. Thank you to the equestrian professionals who scored the ridden horse behavior, in particular the veterinary surgeons from the Minster Veterinary Centre (Nottinghamshire, UK) and from the School of Veterinary Science and Medicine, University of Nottingham, UK.

\section{References}

Cook N.J., Schaefer A.L., Church J.S., 2006. Nutritional therapy modulates stress responses of elk (Cervus elaphus Canadensis) to removal of velvet antler. Online Journal of Veterinary Research 10, 20-25.

Ekman, P., Levenson, R.W., Friesen, W.V., 1983. Autonomic nervous system activity distinguishes between emotions. Science 221, 1208-1210.

Fazio, E., Calabrò, G., Medica, P., Messineo, C. and Ferlazzo, A., 2006. Serum cortisol levels of Quarter horses: circadian variations and effects of training and western riding events. In: Lindner, A. (Editor) Management of Lameness Causes in Sport Horses. Conference on Equine Sports Medicine and Science. Wageningen Academic Publishers, Cambridge, U.K., pp. 175-179. Fazio, E., Molinari, P., Medica, P. Messineo, C. and Ferlazzo, A., 2008. Circulating cortisol levels of Arab sport horses before and after gymkhana riding events: effects of training state, gender and age. In Lindner, A. (Editor) The Acute Poorly Performing Sport Horse. Conference on Equine Sports Medicine and Science. Wageningen Academic Publishers, Cambridge, U.K., pp. 165-171.

Fédération Equestre Internationale, 2009. FEI Rules for Dressage Events, $23^{\text {rd }}$ Ed. Fédération Equestre Internationale, Lausanne, Switzerland.

Freire, R., Buckley, P., Cooper, J.J., 2009. Effects of different forms of exercise on post inhibitory rebound and unwanted behaviour in stabled horses. Equine Veterinary Journal 41, 487-492.

German National Equestrian Federation, 1997. The Principles of Riding: The Official Instruction Handbook of the German National Equestrian Federation. German National Equestrian Federation, Kenilworth, U.K.

Hall, C., Burton, K., Maycock, E., Wragg, E., 2011. A preliminary study into the use of infrared thermography as a means of assessing the horse's response to different training methods. Journal of Veterinary Behavior 6,291-292. 
Hall, C., Huws, N., White, C., Taylor, E., Owen, H., McGreevy, P.D., accepted 2012. Assessment of ridden horse behavior. Journal of Veterinary Behavior doi:

10.1016/j.jveb.2012.05.005.

Heleski, C.R., McGreevy, P.D., Kaiser, L.J., Lavagnino, M., Tans, E., Bello, N., Clayton, H.M., 2009. Effects on behaviour and rein tension on horses ridden with or without martingales and rein inserts. The Veterinary Journal 181, 56-62.

Hockenhull, J., Creighton, E., 2013. The use of equipment and training practices and the prevalence of owner-reported ridden behaviour problems in UK leisure horses. Equine Veterinary Journal DOI: 10.1111/j.2042-3306.2012.00567.x

Kaiser, L., Heleski, C.R., Siegford, J., Smith, K.A., 2006. Stress-related behaviours among horses used in a therapeutic riding program. Journal of the American Veterinary Medicine Association 228, 39-45.

König von Borstel, U., Pasing, S., Gauly, M., 2011. Towards a more objective assessment of equine personality using behavioural and physiological observations from performance test training. Applied Animal Behaviour Science 135, 277-285.

Marlin, D., Nankervis, K., 2002. Equine Exercise Physiology. Blackwell Science, Oxford, U.K., pp 130-132.

McClure, S.R., Murray, M.J., Carithers, D., Gross, S.J., Holste, J.E., 2005. Gastric ulceration in horses exposed to training and activities typical for recreational showing. American Association of Equine Practitioners. Proceedings 51.

McGreevy, P.D., Harman, A., McLean, A., Hawson, L., 2010. Over-flexing the horse's neck: A modern equestrian obsession? Journal of Veterinary Behavior 5, 180-186.

Mitchell, R.D., 2001. Prevalence of gastric ulcers in hunter/jumper and dressage horses evaluated for poor performance. In: Proceedings. Annual Meeting of the Association of Equine Sports Medicine 2001, 74-77.

Nakayama, K., Got, S., Karaoke, K., Nakamura, K., 2005. Decrease in nasal temperature of rhesus monkeys (Macaca mulatto) in negative emotional state.Physiology and Behavior 84, 783790.

Ödberg, F.O., 1987. Chronic stress in riding horses. Equine Veterinary Journal 19, 268-269.

Schmidt, A., Aurich, J., Mőstl, E., Müller, J., Aurich, C., 2010. Changes in cortisol release and heart rate and heart rate variability during the initial training of 3-year-old sport horses.

Hormones and Behavior 58, 628-636.

Stewart, M., Webster, J.R., Schaefer, A.L., Cook, N.J., Scott, S.L., 2005. Infrared thermography as a non-invasive tool to study animal welfare. Animal Welfare 14, 319-325.

Stewart M, Webster J, Verkerk G, Colyn J, Schaefer A., 2007. Non-invasive measurement of stress in dairy cows using infrared thermography. Physiology and Behavior 92, 520-525. Valera, M., Bartolomé, E., Sánchez, M.J., Molina, A., Cook, N., Schaefer, A., accepted 2012. Changes in eye temperature and stress assessment in horses during show jumping competitions. Journal of Equine Veterinary Science doi: 10.1016/j.jevs.2012.03.005

Van Breda, E. 2006. A nonnatural head-neck position (Rollkur) during training results in less acute stress in elite, trained, dressage horses. Journal of Applied Animal Welfare Science 9, 5964.

Von Borstel, U.U., Duncan, I.J.H., Shoveller, A.K., Merkies, K., Keeling, L.J., Millman, S.T., 2009. Impact of riding in a coercively obtained Rollkur position on welfare and fear of performance horses. Applied Animal Behaviour Science 116, 228-236. 
Weeks, J., 1996. Equine agitation behaviours. Equine Practice 18, 23-24.

Yarnell, K., Hall, C., Billett, E. (2013) An assessment of the aversive nature of an animal management procedure (clipping) using behavioral and physiological measures.Physiology and Behavior 118, 32-39. 